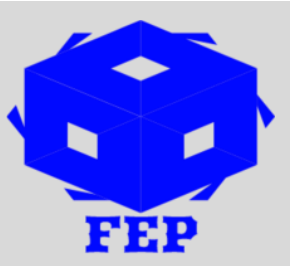

\title{
APPLICATION OF BIOTECHNOLOGY FOR ADDRESSING FOOD SECURITY IN GHANA
}

\author{
Yaw Asare ${ }^{1}$ \\ ${ }^{1}$ Kwadaso Agriculture College, Ghana
}

*Corresponding Author: Yaw Asare

Article Received: 15-05-19

Accepted: $25-08-19$
Published: 05-09-19

Licensing Details: Author retains the right of this article. The article is distributed under the terms of the

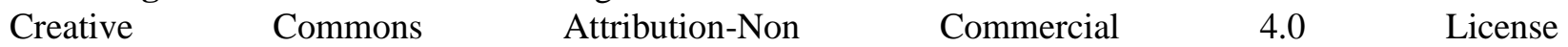
(http://www.creativecommons.org/licences/by-nc/4.0/) which permits non-commercial use, reproduction and distribution of the work without further permission provided the original work is attributed as specified on the Journal open access page.

\section{ABSTRACT}

The contribution of the Horticultural farming for Ghana economy is that it produces horticultural products which generate income for poor farmers and foreign reserves for the country by means of exporting products. With appropriate policies and technologies like biotechnology, horticulture increases the incomes of smallholder farmers, enhancing rural development. Conventional plant breeding techniques have made considerable progress in the development of improved varieties of horticultural products, there is still room for major improvement which can be achieved using the biotechnology. There is the need to integrate biotechnology to speed up crop improvement programs. Biotechnological tools have revolutionized the entire crop improvement programs by providing new strains of plants, supply of planting material, more efficient and selective pesticides and improved fertilizers. This study assesses the relationship between horticultural farming, biotechnology and food security. The impact of biotechnology on the welfare of smallholder farmers is also assessed. The paper concludes that the role of biotechnology in food security in Ghana cannot be overemphasized but still has a long way to go. Agricultural production and productivity problems in developing countries like Ghana go beyond technological solutions alone; already existing challenges of smallholder farmers should be addressed first. Biotechnology could however contribute to sustainable development by increasing agricultural productivity using new breeding techniques. It can also increase the revenues in agricultural production.

Keywords: Biotechnology, Food Security, Horticulture and Smallholder Farming 


\section{INTRODUCTION}

Insecurity of food is the problem of entire world and Africa is no exception. The chronic food insecurity in African region is because about $85 \%$ of agricultural production is rain-dependent. Also, domestic food production contributes almost $80 \%$ of the total need for the food. The food security problem is accompanied with high unemployment and poverty in the region. With the introduction of economic reforms notwithstanding, economic development in many African countries remains slow, which is having negative influence on wellbeing of the rural poor in particular. Natural disasters also creates further problem.

Food production is the main profession of many smallholder farmers in Ghana; as many as about 70 per cent of farmers are smallholders (Afari-Sefa, 2008). The old methods of farming of these farmers is a challenge in raising production of agriculture and horticultural products. Common problems are limited access to new technology, labor inefficiencies, land related problems, , high yielding seed varieties, limited access to credit, markets and so on. These challenges have greatly affected their efficiency, productivity and yields dramatically.

In this challenging situation, government and donor agencies have focused more towards research and development activity related to agriculture and farming. Biotechnology is playing its role in this domain because it can lead to higher production and thus improve wellbeing of individuals, families and region.

Biotechnology is now considered as a solution to food insecurity problem. These technologies can be used to speed up traditional ways of plant breeding for instance. Biotechnology can be used as a major tool to boost crop yields and reduce production costs for smallholder farmers. Objectives of the Study

(i) To review horticultural farming in Ghana

(ii) To discuss the perceived risks and benefits of biotechnology adoption

(iii) To determine the potential of biotechnology in increasing the productivity of horticultural farming in Ghana.

\section{Horticultural Farming in Ghana}

Agriculture remains the largest source of export revenue for most African countries and the largest income generator for their populations. In African region, the production and marketing of agriculture products remains a major source of income. About $70 \%$ of the population in SubSaharan Africa is largely dependent on the production and export of agricultural commodities including horticulture (Gioe, 2006). Horticulture is the production and marketing of crops (such as fruits and vegetables) that have with a relatively high value per unit or high perishable character, produced under intensive use of labour, land, and other inputs (Afari-Sefa, 2008). Mostly, horticultural products are produced for export purpose. Through the implementation of relevant policies and suitable technology, horticultural production can significantly contribute towards increasing the incomes of farmers especially smallholder farmers, expanding employment opportunities, enhancing rural development and contributing towards foreign exchange earnings (USAID, 2005). Ghana in comparison to its neighbors is in advantageous position to export products to Europe due to its location. Additionally business environment and 
travel costs compare favorably with her neighbor. However, low-productivity supply chains may result from the low unit of agricultural production in Sub-Saharan Africa. It may also be that a majority of producers of agricultural products in Africa are smallholders. According to Maertens \& Swinnen (2006), in Africa, majority of fruit and vegetable cultivation for both domestic consumption and for export continues to be dominated by small-scale farms. In Ghana, smallholder farmers account for about 70 per cent of horticultural producers (GEPA, 2010). In spite of the successes of many African exporters in selling on new markets, if there are no advancements to their executions of businesses on the export market, many risk being trapped by producing low-skill, low-value products and services. This means they would struggle to obtain a significant value-added share in the world market. The efficient operations of agricultural supply chains are important for the success of the SSA rural poor in terms of their income. According to GEPA (2010), is because about $15 \%$ of the population of Ghana depends on horticultural exportrelated production and/or marketing for their livelihood. The Ministry of Food and Agriculture has therefore put in place the Horticulture Export Industry Initiative (HEII) to see to the development of horticulture in Ghana. The Ministry of Trade and Industry has also formulated a national export strategy focusing on increasing revenue from nontraditional exports. In view of this, the Trade Ministry has implemented the Private Sector Development Strategy (PSDS II) that is aimed at developing a thriving sector to improve the wellbeing of Ghanaians. Despite government efforts, the market position and customer perception towards the Ghana products is still not very favorable. Some improvement is made in this regard but still there is scope for improvement.

\section{Welfare Implications of Horticultural Farming in Ghana}

For developing countries development, it is advised that they improve their farming method, adopt latest technology, and improve products nature. Horticulture has important welfare implications for rural households. The effects may be in various ways, through product and labour markets, and through direct and indirect mechanisms. The continual growth in horticulture has led to debates among academics, policy-makers and the development partners on horticulure's overall welfare implications. Some recommend the improvement in horticultural as a solution to the poverty problem, while, other consider it as not a good solution since it also leads to income inequalities. In order to understand the overall welfare implications of the growth in modern food supply chains for rural households, it is necessary to take into account and distinguish between several different effects. The growth in horticulture in developing countries can bring about important positive welfare effects for rural development and poverty reduction. These effects can come in various ways through product effects on income and contribute immensely towards welfare and development. This implies a need for supporting the development of horticulture especially smallholder horticultural farmers in poor countries.

\section{Biotechnology and Horticultural Farming in Ghana}

Agriculture, especially horticultural crop farming has been the mainstay of the rural economy. The agriculture sector in Ghana face several challenges including limited access to credit facilities, pests and diseases, prevalence of weeds, low levels of irrigation, limited access to labor 
and capital input, floods, and drought. These challenges limited the ability of farmers to get suitable income and raise the quality of life. Also it reduces the ability to tackle poverty challenge. Since farmlands are the major natural resources in rural Ghana, households continue to produce in the midst of these devastating conditions over the years that seem to confine them to abject poverty. The application of biotechnology in other parts of the world seems to provide solution to the bulk of the production bottlenecks associated with horticultural farming in Ghana. Studies over the years show that application of biotechnologies in the field of GMOs for instance has been beneficial to farmers in some developing countries. The first GMOs became commercially available in the mid-1990s; and since then, their relevance to the agricultural production sector has not waned.

Consequently, the number of GM crop varieties has increased significantly and the area sown to GM crops has also seen appreciable increases. Adoption across countries has however not been even, with almost the entire expansion taking place in developed countries. Also, in spite of the increasing availability of various varieties of GM products, commercial success has been concentrated on a few varieties or traits. In those countries where GM crops are applied, principal benefits reported include productivity gains, cheaper and improved food quality, minimized pests and disease infestation, and the ability to save and improve land resources among others. These benefits notwithstanding, the adoption of such technologies appears not widespread among Ghanaian horticultural farmers, especially the rural smallholder farmers. Limitations to the adaptation of these biotechnologies may be due to inability to meet the initial costs of such technologies, especially by poor rural farm households. There are also debates over the safety and the long term impacts of the adoption of such technologies thereby leaving farmers in a state of dilemma, whether to adopt these technologies or not. The role of research, and relevant policy tools combined with some financial assistance to farmers willing to adopt these technologies would be useful if the expected gains from the adoption of these technologies are to be realized by farmers in Ghana.

\section{Benefits of Biotechnology}

The potential socio-economic benefits of the applications of biotechnology abounds in the extant literature. Enhanced food production via insect control, disease, insect and weed resistant seeds; nutritional enhancement are strongly proposed as potentials likely to follow the application of biotechnology (Mackey, 2003). Overall, biotechnology is considered as a good source of improving food security and economic problems in the drought hit region of the world. These technologies change the fundamental method of farming and thus better address the challenges faced. Biotechnology can be used as a major tool to boost crop yields and reduce production costs for smallholder farmers. Biotechnology can also help in researching drought-resistant varieties of crops that will adapt well to the harsh environmental conditions. It can also help solve land issues by maximizing the use of the limited land available to cultivate and derive the maximum returns from a given piece of land; thus further inuring to environmental conservation gains. The crucial role of biotechnology in the economic transformation and sustainable development of the developing world has assumed increased significance as a result of a variety 
of factors involving increasing food prices, increasing food insecurity, commercialization of genetically engineered products, and fast technological advances

\section{Potential of Biotechnology in Increasing Productivity of Horticultural Farming}

There is no aspect of plant production that will not undergo profound changes as a result of the application of biotechnology, nonetheless in horticulture. Commercial applications of plant genetic engineering have not yet occurred. Presently, many traditional aspects of biotechnology such as tissue culture have been of major importance, especially in the acceleration of the breeding process for new varieties and in the multiplication of disease-free seed material.

Biotechnology can be used in many ways to achieve higher yields; for example by improving flowering capacity and increasing photosynthesis or the intake of nutritive elements. Breeding of horticultural plant species has been enhanced considerably by in vitro development of improved varieties that tend to be better adapted to particular environments. The application of tissue culture attributed to this in many ways such as:

(i) the rapid reproduction and multiplication of cultivars (produced by selective breeding)

(ii) the production of healthy cultivars, free of viruses and pathogenic agents;

(iii) the rapid adaptation and selection of cultivars that are resistant to specific stress factors (for instance, salinity and acid soils);

(iv) the availability of seed material throughout the year (rather than seeds which are subject to the seasonal cycle);

(v) the possibilities to produce species that are difficult to reproduce or that reproduce and grow slowly; and

The application of tissue culture does not require very expensive equipment, thus technology can be applied easily in developing countries that in turn helps to improve other varieties of horticultural crops. Biotechnology aids in the reduction of the need for agro-chemicals that small farmers in developing countries often cannot afford. A reduction in the use of agrochemicals implies fewer residues in the final product. Worldwide, nitrogen-fixing bacteria are being used increasingly to inoculate the soil, thus allowing reduced inputs of fertilizer that is expensive and often presents a heavy drain on the scarce foreign exchange resources of developing countries. Biotechnology helps to identify the strains of bacteria most suitable for specific crops and soils and to multiply them for large scale use. There are about a hundred fungus species with insecticidal effects known today. Biotechnology can facilitate the mass production of these fungi in a storable form and the use of these products may be less expensive than that of agrochemicals. As living organisms, they will multiply under favorable conditions depending on the intensity of the pests to be controlled. In addition, improved screening techniques at an early stage may reduce the amount of agrochemicals needed to fight specific diseases. The potential of biotechnology for increasing horticulture productivity is vast indeed. The fact that such a capability exists, however, does not assure that it will be realized. Obstacles frequently stand in the way of the application of new technologies in horticultural farming.

Some of these obstacles are: 
(i) weak linkages between international and national research institutions;

(ii) poor communication between national research institutions and farmers;

(iii) a lack of support measures (credit schemes, regular provision of improved seeds, demonstration plots and marketing outlets); and

(iv) Landholding structures which dampen the interest of landlords and tenants in introducing new technologies.

Biotechnology has tremendous potential for promoting horticultural farming. However, where the application of this new technology aims to increase productivity in the export sectors, the successes in this area could be at the expense of the market position of others. In such cases, international competition may endanger cooperation between other fields of farming and could impact other technologies that seem necessary for the application of biotechnologies that are specifically suited to their interests.

\section{CONCLUSION}

From the arguments made so far, it is evident that the role of biotechnology in food security in Ghana and other developing countries remain one of the greatest developmental concerns over the years. Agricultural production and productivity problems in developing countries like Ghana go beyond technological solutions alone. It could however contribute to sustainable development by increasing agricultural productivity using new breeding techniques. It can also increase the revenues of agricultural production. This notwithstanding, the application of agricultural biotechnology in developing countries is not without debate. From a human welfare standpoint, the greatest benefits of plant biotechnology will surely be derived from the adoption of improved crop varieties in the developing countries of the world where billions of people still depend on agriculture for their livelihoods. Finally, the paper generally agrees with Makinde et al (2009) that agricultural biotechnology alone is certainly not a panacea to the multitude of problems that farmers in Africa face; however, it has the potential to make crop breeding and crop management systems more efficient thereby generating improved crop varieties and higher yields.

Based on the conclusions made, some recommendations are suggested. Firstly, for biotechnology to have the desired effect on productivity and thus food security there is the need to first of all tackle the myriad of challenges faced by smallholder farmers in Ghana. Secondly, it is necessary to build the required capacity to generate plant biotechnologies and then incorporate these into our national crop improvement programs. Thirdly, it will also be important for Ghana to establish the required intellectual property rights and regulatory policies that will assure safety and encourage the private sector to develop and market these new crop varieties. Finally, both public and private sector research institutions in Ghana should be empowered to continue producing and delivering products and research that are targeted towards the needs of poor farmers and consumers.

\section{References}

Afari-Sefa, V. (2008). Horticultural exports and livelihood linkages of rural dwellers in southern Ghana: An agricultural household modeling application. The Journal of Developing Areas, 4(1), 1- 23. 
Benbrook, C. M. (2012). Impacts of genetically engineered crops on pesticide use in the US the first sixteen years. Environmental Sciences Europe, 24(24), 2190-4715.

Carpenter, J. E. (2011). Impact of GM Crops on Biodiversity. GM Crops, 2(1), 7-23.

De Coppi, P., Bartsch, G. Jr., Siddiqui, M. M. (2007). Isolation of amniotic stem cell lines with potential for therapy. Nature Biotechnology, 25(1). 100106.

Freebairn, D. K. 1995. Did the Green Revolution concentrate incomes? A quantitative study of research reports. World Development 23(2), 265-279.

GEPA (2010), Export Performance Report, GEPA Annual Report, Accra.

Gioe, M. (2006). Can horticultural production help African smallholders to escape dependence on export of tropical agricultural commodities? Crossroads, 6(2), 16-65.

International Fund for Agricultural Development (IFAD) (2012). The future of world food and nutrition security: Investing in smallholder agriculture-an international priority. Available https://www.ifad.org/en/topic/tags/food_and_nutrition_security/1952762Accessed 11-052016.

Lipton, M. (1989). New seeds and poor people. London: Unwin Hyman.

Mackey, M. A. (2003). The Developing World Benefits from Plant Biotechnology. Journal of Nutrition Education and Behavior, 35(4), 210-214.

Maertens, M., \& Swinnen, J. (2006). Standards as barriers and catalysts for trade and poverty reduction. In IAAE Conference Papers (1-34).

Morse, S. (1995). Biotechnology: A servant of development? In People and Environment, S. Morse and M. Stocking (eds.), 131-154. UCL Press: London.

Makinde, D., Mumba, L., \& Ambali, A. (2009). Status of Biotechnology in Africa: Challenges and opportunities. Asian Biotechnology and Development Review, 11(3), 1-10.

Tabashnik, B. E., Patin, A. L., Dennehy, (2000). Frequency of resistance to Bacillusthuringiensisin field populations of pink bollworm. Proceedings of the National Academy of Sciences of the United States of America 97 (24), 12980-12984.

USAID (2005). Horticulture market assessment study: A look at the Export Potential. A report for prepared for USAID.

Wang, Z. J., Hai, L., Huang, J. K., et al (2009). Bt cotton in China: Are secondary insect infestations offsetting the benefits in farmer fields?. Agricultural Sciences in China, 8(1), 83-90.

Warwick, S. I., Legere, A., Simard, M. J., \& James, T. (2008). Do escaped transgenes persist in nature? The case of an herbicide resistance transgene in a weedy Brassica rapa population. Molecular Ecology, 17(5), 1387-1395.

Webber, C. M., \& Labaste, P. (2010). Building co Guide to value chain concepts and applications.: Agriculture and Rural Development Series, The International Bank for Reconstruction and Development/The World Bank. 